\title{
Ethanol-eluted Extract of Rhus verniciflua Stokes Inhibits Cell Growth and Induces Apoptosis in Human Lymphoma Cells
}

\author{
Jeong-Chae Lee, Ju Kim* and Yong-Suk Jang* \\ Division of Biological Sciences, Research Center of Bioactive Materials and ${ }^{*}$ Bank for Cytokine Research, \\ Chonbuk National University, Chonju 561-756, Korea
}

Received 17 January 2003, Accepted 11 February 2003

\begin{abstract}
Rhus verniciflua Stokes (RVS) has been used as a traditional herbal medicine. Several earlier studies indicated that an ethanol extract of RVS has both antioxidant and anti-tumor properties, although the mechanism for the activity remains to be elucidated. In this report, we prepared a highly purified ethanol extract from RVS, named REEE-1 ( $\underline{\text { Rhus }}$ ethanol eluted extract-1), and investigated the mechanism involved in its growthinhibitory effect on the human $B$ and $T$ lymphoma cell lines, BJAB and Jurkat, respectively. Results from tritium uptake proliferation assays showed that the proliferative capacities of both BJAB and Jurkat cells were strongly suppressed in the presence of REEE-1. This was further confirmed through trypan blue exclusion experiments that revealed a dose-dependent decrease in viable cell numbers after REEE-1 treatment. REEE-1-mediated suppression of cell growth was verified to be apoptotic, based on the increase in DNA fragmentation, low fluorescence intensity in nuclei after propidium iodide staining, and the appearance of DNA laddering. In particular, REEE-1 exerted its anti-oxidant activity through the inhibition of hydroxyl radical-mediated degradation by iron ion chelation rather than direct scavenging of hydroxyl radicals. Furthermore, REEE-1 was revealed to be a potential scavenger of superoxide anions. Collectively, our findings suggest that REEE-1 is a natural anti-oxidant that could be used as a cancer chemo-preventive and therapeutic agent.
\end{abstract}

Keywords: Anti-oxidant, Anti-tumor, Apoptosis, Human lymphoma cells, Rhus verniciflua Stokes

*To whom correspondence should be addressed.

Tel: 82-63-270-3343; Fax: 82-63-270-4312

E-mail: yongsuk@moak.chonbuk.ac.kr

\section{Introduction}

In recent years, there has been a global trend toward the use of natural substances present in fruits, vegetables, and herbs as anti-oxidants and functional foods (Farr, 1997; Wang et al., 1997; Lee et al., 1999b; Kitts et al., 2000; Lee and Lim, 2001). In addition, several of these substances are believed to have potential value as cancer chemopreventive or therapeutic agents in vivo. Some vitamins and their derivatives have important biological roles related to cancer prevention and free radical scavenging (van Poppel and van den Berg, 1997), and some phytochemicals, such as taxol (Mukherjee et al., 2001), oncovin (Christou et al., 2001), and captothecin (Pezutto, 1997), are currently used in cancer treatment. Most of these bioactive substances exert their cancer chemotherapeutic activity by blocking cell cycle progression and triggering apoptotic cell death. Therefore, induction of apoptosis in tumor cells has become an indicator of the tumortreating ability of naturally derived bioactive substances (Smets, 1994; Paschka et al., 1998).

Rhus verniciflua Stokes (RVS) has traditionally been used in Korean herbal medicine (Jung, 1998; Hong et al., 1999). Recently, various RVS biological activities have been reported by a number of investigators. For example, an ethanol extract from RVS was found to have an anti-oxidant effect against hydroxyl radicals and anti-proliferative activity in human cancer cell lines (Lee et al., 1999a; Lim et al., 2000). In a previous report, we prepared a highly purified ethanol extract from RVS, named REEE-1, and demonstrated its potential activity in scavenging hydroxyl radicals (Lee et al., 2001a). Since it has been suggested that there is a very close relationship between anti-oxidant and anti-tumor activities, we assumed that REEE-1 had potential value as an anti-tumor promoting agent. Consequently, in this study we tried to confirm the assumption by evaluating the growth inhibitory effect of the REEE-1 on human lymphoma cells, BJAB, and Jurkat cells, and elucidating the mechanism(s) involved in the action of REEE-1. In addition, we further defined the 
antioxidant properties of REEE-1 via a cell-free radical generation system.

\section{Materials and Methods}

Chemicals Unless otherwise specified, chemicals and plastics used in this study were purchased from Sigma Chemical Co. (St. Louis, USA) and Falcon Labware (Becton-Dickinson, Franklin Lakes, USA), respectively.

Preparation of REEE-1 REEE-1 was prepared from the ethanol extract of RVS as described previously (Lee et al., 2001a). Quality and purity of REEE-1 were assessed using EI-MS and NMR spectra, which were serviced by Korea Basic Science Institute (Yusung, Korea), and it has been shown that there is no contamination of urushiols in REEE-1 preparation. REEE-1 was freshly dissolved with absolute ethanol and final ethanol concentration did not exceed $0.1 \% \quad(\mathrm{v} / \mathrm{v})$ throughout the experiments. Concentrations used in this experiment were expressed as the dry weight of the REEE-1 $(\mu \mathrm{g} / \mathrm{ml})$.

Cell culture and treatment Human B and T lymphoma cells, BJAB and Jurkat, respectively, were cultured in RPMI-1640 supplemented with $10 \%$ fetal bovine serum (FBS; HyClone, Logan, USA). One million cells per milliliter were resuspended in either $2 \mathrm{ml}$ or $100 \mu \mathrm{l}$ media for spreading onto either $35-\mathrm{mm}$ culture dishes or 96-well flat-bottomed plates, respectively. Before the REEE-1 treatment, cultures were switched to medium supplemented only with $0.5 \%$ FBS. At the varied times after the treatment, the cells were processed for the analyses of DNA synthesis, cytotoxicity, and apoptosis. Concentrations of REEE-1 tested, ranged from 0.1 to $10 \mu \mathrm{g} / \mathrm{ml}$, did not cause any toxicity against mouse thymocytes in primary cell culture (Lee et al., 2001b).

Measurement of DNA synthesis Level of DNA synthesis by incubating the cells with different concentrations $(0.1-10 \mu \mathrm{g} / \mathrm{ml})$ of REEE-1 was measured by adding $1 \mu \mathrm{Ci}$ of $\left[\right.$ methyl $\left.{ }^{3} \mathrm{H}\right] \mathrm{TdR}$ (Amersham Pharmacia Biotech., Buckinghamshire, UK) to each well for the last $24 \mathrm{~h}$ during varied culture periods. Cells were then collected with a cell harvester (Inotech Inc., Dottikon, Switzerland), and the tritium contents were measured using a liquid scintillation counter (Packard Instrument Co., Downers Grove, USA).

Determination of cytotoxicity Cellular cytotoxicity induced by REEE-1 treatment was measured using trypan blue exclusion method (Hongo et al., 1986). Briefly, BJAB and Jurkat cells were cultured in RPMI-1640 supplemented with $0.5 \%$ FBS in the presence of 0.1 to $10 \mu \mathrm{g} / \mathrm{ml}$ of REEE- 1 . At varied time points during the culture period $(0-24 \mathrm{~h})$, the cells were stained with $0.4 \%$ trypan blue and about 100 cells were counted for each treatment condition. Cytotoxicity was calculated as follows; cytotoxicity (\%) $=[$ (total cells - viable cells $) /$ total cells $] \times 100$.

Analysis of apoptosis Aliquots of BJAB or Jurkat cells were placed in $35 \mathrm{~mm}$ culture dishes, exposed to REEE-1 for varied times, and then analyzed by terminal deoxynucleotidyl transferase
(TdT)-mediated dUTP nick-end labeling (TUNEL), flow cytometry, and DNA fragmentation assays to detect the apoptosis. For TUNEL assay, cells were fixed with $1 \%$ buffered formaldehyde (pH 7.5) for $30 \mathrm{~min}$ on ice. Cells were then washed with PBS, resuspended in $70 \%$ ice-cold ethanol, and kept at $20^{\circ} \mathrm{C}$ for $1 \mathrm{~h}$. The cells were rehydrated with PBS and incubated in TdT buffer containing $30 \mathrm{mM}$ Tris- $\mathrm{HCl}$ (pH 7.2), $140 \mathrm{mM}$ sodium cacodylate, $1 \mathrm{mM} \mathrm{CoCl}{ }_{2}, 0.05 \mathrm{mg} / \mathrm{ml} \mathrm{BSA}, 0.1 \mathrm{mM}$ DTT, $7.5 \mathrm{U} / \mathrm{ml} \mathrm{TdT}$, and $0.4 \mathrm{nM} / \mathrm{ml}$ FITC-5-dUTP. After a 30 -min incubation at $37^{\circ} \mathrm{C}$, reaction and non-specific binding were blocked by adding the buffer containing $300 \mathrm{mM}$ sodium chloride, $30 \mathrm{mM}$ sodium citrate, and $2 \%$ bovine serum albumin. Finally, cells were washed with PBS and observed under a fluorescence microscope (Axioskop 2, Carl Zeiss, Oberkochen, Germany).

For flow cytometric analysis, the suspension $\left(2 \times 10^{6}\right.$ cells $)$ of REEE-1-treated cells was fixed overnight at $4^{\circ} \mathrm{C}$ with $80 \%$ ethanol and then incubated overnight at $4^{\circ} \mathrm{C}$ with $1 \mathrm{ml}$ of propidium iodide (PI) staining mixture $(250 \mu \mathrm{l}$ of PBS, $250 \mu \mathrm{l}$ of $1 \mathrm{mg} / \mathrm{ml}$ RNase in $1.12 \%$ sodium citrate, and $500 \mu \mathrm{l}$ of $50 \mu \mathrm{g} / \mathrm{ml} \mathrm{PI}$ in $1.12 \%$ sodium citrate). After the staining, $1 \times 10^{4}$ cells were analyzed with FACS Vantage $^{\circledR}$ system (Becton Dickinson, San Jose, USA).

For the DNA fragmentation assay, lymphoma cells were incubated with lysis buffer (1\% NP-40 and 1\% SDS in 50-mM Tris- $\mathrm{HCl}, \mathrm{pH} 8.0$ ) for $1 \mathrm{~h}$ at $65^{\circ} \mathrm{C}$. DNA was extracted with phenol/ chloroform/isoamyl alcohol and the degree of fragmentation was analyzed using $2 \%$ agarose gel electrophoresis followed by ethidium bromide staining.

Measurement of antioxidant activity $\mathrm{We}$ measured the scavenging activity of REEE-1 against hydroxyl radicals $\left({ }^{\circ} \mathrm{OH}\right)$ and superoxide anions $\left(\mathrm{O}_{2}{ }^{-}\right)$using two different assays such as deoxyribose and NBT assays. Initially, deoxyribose assay to determine the rate constant for the reactions between either antioxidants and hydroxyl radicals (referred as non-site-specific scavenging assay) or anti-oxidants and iron ions (referred as sitespecific scavenging assay) was conducted as described by Halliwell et al. (1987). For non-site-specific scavenging assay, varied concentrations of REEE-1 were mixed with $1 \mathrm{ml}$ reaction buffer $\left(100 \mu \mathrm{M} \quad \mathrm{FeCl}_{3}, \quad 104 \mu \mathrm{M} \quad\right.$ EDTA, $\quad 1.5 \mathrm{mM} \quad \mathrm{H}_{2} \mathrm{O}_{2}, \quad 2.5 \mathrm{mM}$ deoxyribose, and $100 \mu \mathrm{M}$ L-ascorbic acid, $\mathrm{pH}$ 7.4) and incubated for $1 \mathrm{~h}$ at $37^{\circ} \mathrm{C}$. One milliliter of $0.5 \%$ 2-thiobarbituric acid in 0.025 $\mathrm{M} \mathrm{NaOH}$ and $1 \mathrm{ml}$ of $2.8 \%$ trichloroacetic acid were added to the mixture and heated for $30 \mathrm{~min}$ at $80^{\circ} \mathrm{C}$. Finally, the mixture was cooled on ice and absorbance was measured at $532 \mathrm{~nm}$ using a spectrophotometer (DU ${ }^{\circledR} 530$, Beckman, Krefeld, Germany).

Site-specific scavenging activity, which represents the ability of REEE-1 to chelate iron ions and interfere with hydroxyl radical generation, was measured using the same reaction buffer without EDTA. In addition, the ability of REEE-1 to reduce $\mathrm{Fe}^{3+}$-EDTA complex to $\mathrm{Fe}^{2+}$-EDTA complex, acting as pro-oxidant, was tested using the non-site-specific scavenging assay mixture without the addition of ascorbic acid. Solutions of $\mathrm{FeCl}_{3}$ and ascorbate were made up in distilled water immediately before use.

Scavenging activity on superoxide radical was accessed by the method described by Gotoh and Niki (1992) with a slight modification. Briefly, different concentrations of REEE-1 were added to the reaction solution containing $100 \mu \mathrm{l}$ of 30 -mM EDTA ( $\mathrm{pH} 7.4$ ), $10 \mu \mathrm{l}$ of 30-mM hypoxanthine in $50 \mathrm{mM} \mathrm{NaOH}$, and 200 
$\mu \mathrm{l}$ of $1.42-\mathrm{mM}$ nitro blue tetrazolium (NBT). After pre-incubation at room temperature for $3 \mathrm{~min}, 100 \mu \mathrm{l}$ of $0.5 \mathrm{U} / \mathrm{ml}$ xanthine oxidase was added to the mixture and the volume was brought up to $3 \mathrm{ml}$ with $50 \mathrm{mM}$ phosphate buffer ( $\mathrm{pH}$ 7.4). After incubation at room temperature for $20 \mathrm{~min}$, absorbance was measured at $560 \mathrm{~nm}$. The inhibitory effects of REEE-1 on either activity of hydroxyl radicals or superoxide radicals were calculated as follows; inhibition (\% control $)=\left[\left(\mathrm{OD}_{\text {control }}-\mathrm{OD}_{\text {sample }}\right) / \mathrm{OD}_{\text {control }}\right] \times 100$.

Statistical analysis All the results were expressed as the mean \pm standard error (SE). An one-way ANOVA using SPSS v 10.0 software was used to make a statistical comparison among the groups and a value of $P<0.05$ was considered as significant.

\section{Results}

Effects of REEE-1 on DNA synthesis in BJAB and Jurkat cells The effect of REEE-1 on DNA synthesis was determined by tritium incorporation into cells. As shown in Fig. 1A, the addition of REEE-1 to cultured cells dramatically inhibited DNA synthesis in a dose-dependent manner. When $1 \mu \mathrm{g} / \mathrm{ml}$ of REEE-1 was added to BJAB cells, tritium uptake
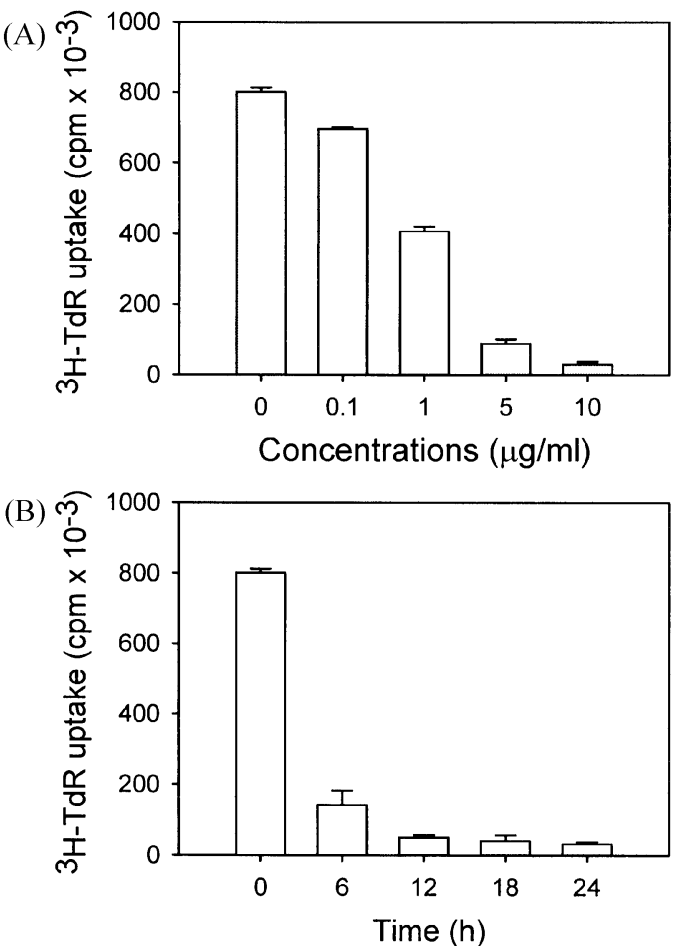

Fig. 1. Effects of REEE-1 on DNA synthesis in BJAB cells. (A) $\mathrm{BJAB}$ cells were treated with the indicated concentrations of REEE-1 for $24 \mathrm{~h}$ in low serum conditions and then incubated for $24 \mathrm{~h}$ in the presence of $\left[\right.$ methyl $\left.^{3} \mathrm{H}\right] \mathrm{TdR}$. (B) BJAB cells were treated with $10 \mu \mathrm{g} / \mathrm{ml}$ of REEE-1 for the indicated times and exposed to $\left[\right.$ methyl $\left.{ }^{-3} \mathrm{H}\right] \mathrm{TdR}$ for the last $24 \mathrm{~h}$. A representative result from three separate experiments is shown and each bar represents the mean \pm SE of triplicates. was $406,927 \pm 13,817 \mathrm{cpm}$, representing a decrease of about $50.7 \%$ from the uptake in untreated cells $(801,689 \pm$ $11,669 \mathrm{cpm})$. Treatment with $5 \mu \mathrm{g} / \mathrm{ml}$ of REEE-1 almost completely inhibited tritium uptake by $\mathrm{BJAB}$ cells, with an incorporation of only $88,965 \pm 12,202 \mathrm{cpm}$. In addition, REEE-1-mediated inhibition of DNA synthesis in BJAB cells was time -dependent (Fig. 1B). Similar inhibition of DNA synthesis was also observed in Jurkat cells (data not shown). These findings indicate that REEE-1 inhibited the growth of human lymphoma cells depending on dose and length of treatment.

Cytotoxic effects of REEE-1 on BJAB and Jurkat cells We next tested the cytotoxic effect of REEE-1 on cultured lymphoma cells. The addition of REEE-1 exerted a cytotoxic effect in a dose- and time-dependent manner (Fig. 2). Following a 24-h incubation with $1 \mu \mathrm{g} / \mathrm{ml}$ of REEE-1 in BJAB and Jurkat cells, cytotoxicity was determined to be 13.6 and $15.7 \%$, respectively. However, when $10 \mu \mathrm{g} / \mathrm{ml}$ of REEE-1 was added, a significant increase in cytotoxicity was observed, such that more than $43 \%$ of $\mathrm{BJAB}$ and $54 \%$ of Jurkat cells were positively stained with trypan blue (Fig. 2A). Furthermore, a time-dependent increase in REEE-1-induced

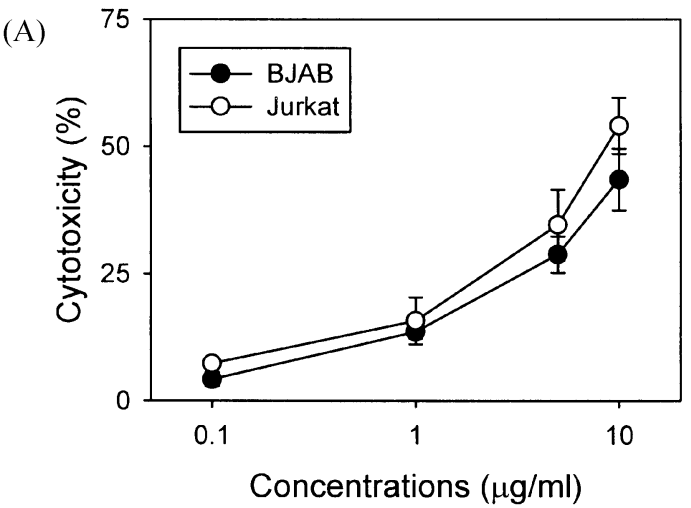

(B)

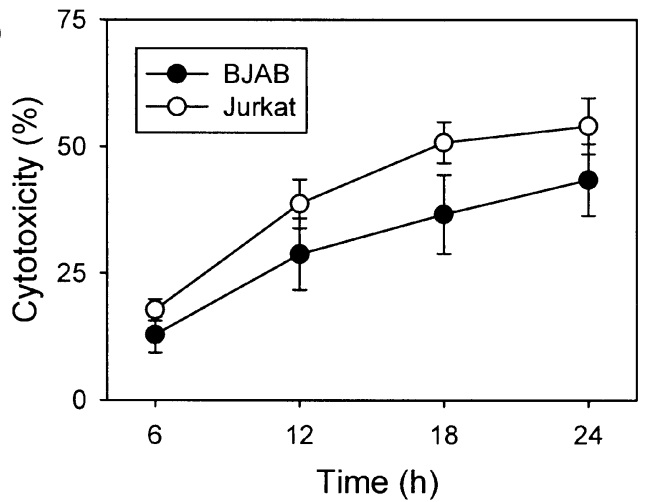

Fig. 2. Cytotoxic effects of REEE-1 in human lymphoma cell lines. (A) BJAB (O) and Jurkat cells $(O)$ were treated with the indicated concentrations of REEE-1 for $24 \mathrm{~h}$. (B) The lymphoma cells were incubated with $10 \mu \mathrm{g} / \mathrm{ml}$ of REEE-1 for the indicated times. A representative result from three separate experiments is shown and each bar represents the mean \pm SE of triplicates. 
(A)

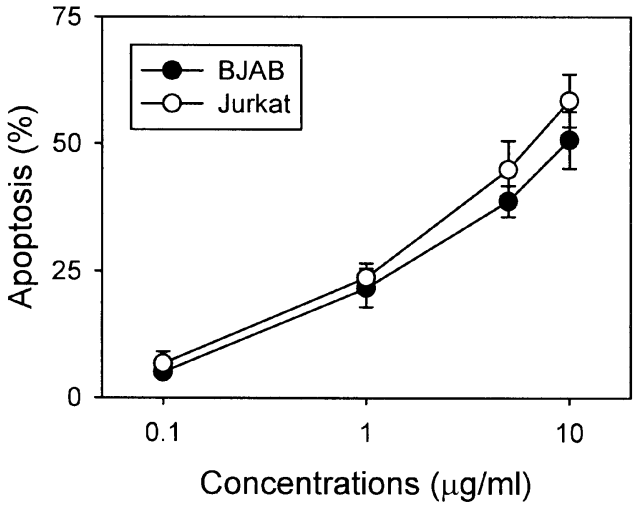

(B)

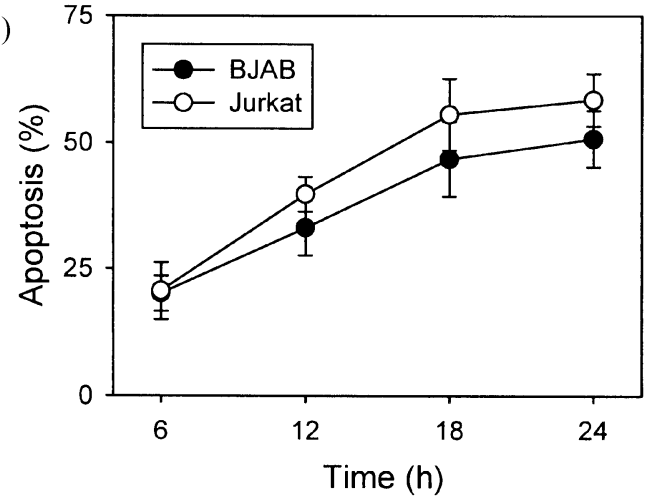

Fig. 3. TUNEL staining of human lymphoma cells. (A) BJAB (O) and Jurkat cells ( $\bigcirc$ ) were treated with various concentrations $(0-10 \mu \mathrm{g} / \mathrm{ml})$ of REEE-1 for $24 \mathrm{~h}$. (B) The cells were exposed to $10 \mu \mathrm{g} / \mathrm{ml}$ of REEE-1 for various lengths of time (0-24 h). After incubation, the lymphoma cells were stainer with FITC-conjugated dUTP and the degree of apoptosis wa: assessed as described in Materials and Methods.

cytotoxicity was detected (Fig. 2B). These results suggest that the REEE-1-mediated inhibition of lymphoma cell proliferation might be due to a cytotoxic rather than a cytostatic effect.

REEE-1 induced apoptotic death of BJAB and Jurkat cells To understand the characteristics of the cytotoxic effect of REEE-1 on lymphoma cells, REEE-1-treated lymphoma cells were subjected to apoptosis assays including TUNEL assay, PI staining of nuclei, and agarose gel electrophoresis of genomic DNA (as described in Materials and Methods). Initially, we noted a dose- and time-dependent increase in the number of positively stained lymphoma cells by TUNEL assay after REEE-1 treatment (Figs. 3A and B). Following exposure to $10 \mu \mathrm{g} / \mathrm{ml}$ of REEE-1, about $20 \%$ of cells were apoptotic after $6 \mathrm{~h}$. However, $50.7 \%$ of BJAB and $58.4 \%$ of Jurkat cells were apoptotic $24 \mathrm{~h}$ after treatment (Fig. 3B). Next, the apoptotic cell death induced by REEE-1 treatment was additionally confirmed through PI staining (Fig. 4). Following treatment with $10 \mu \mathrm{g} / \mathrm{ml}$ of REEE-1 for $24 \mathrm{~h}$, $43.4 \%$ of BJAB cells became apoptotic (Fig. 4A), while more than $50 \%$ of Jurkat cells were apoptotic after the same
(A)

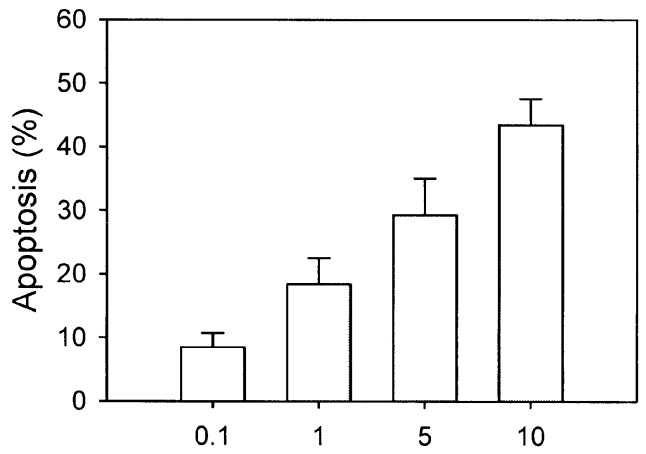

(B)

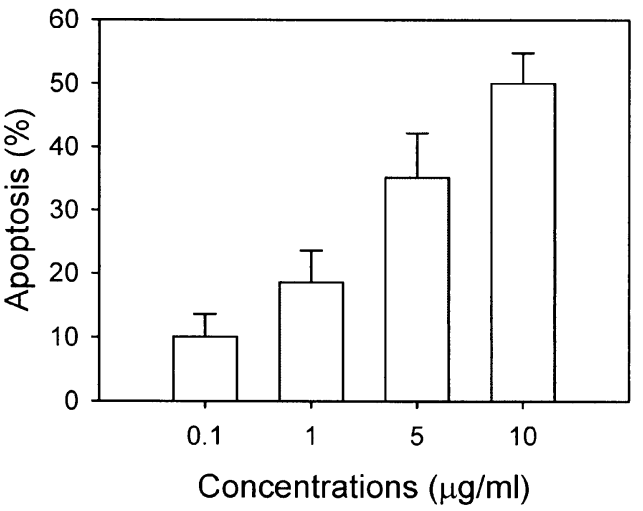

Fig. 4. Flow cytometric analyses of lymphoma cells after PI staining. The incubated BJAB (A) and Jurkat cells (B) wers treated with various concentrations $(0-10 \mu \mathrm{g} / \mathrm{ml})$ of REEE- 1 for $24 \mathrm{~h}$. Each bar represents the mean \pm SE of the cell populations defined as apoptotic, and a representative result from threr separate experiments is shown.

treatment (Fig. 4B). Finally, the increase in REEE-1-mediated apoptosis of lymphoma cells was confirmed by examining DNA ladder formation after REEE-1 treatment (Fig. 5). Treatment with $10 \mu \mathrm{g} / \mathrm{ml}$ of REEE-1 transparently induced the apoptotic laddering of genomic DNA in Jurkat cells (lane 3). In addition, the REEE-1-mediated appearance of apoptotic DNA laddering was also found when BJAB cells were exposed to the REEE-1 (data not shown).

Anti-oxidant properties of REEE-1 We identified the mechanisms involved in REEE-1-mediated anti-oxidant activity, and determined whether REEE-1 decreased hydroxyl radical generation by chelating metal ions or by directly scavenging hydroxyl radicals. The effect of REEE-1 on hydroxyl radicals generated by $\mathrm{Fe}^{3+}$ ions was measured by determining the degree of deoxyribose degradation, an indicator of thiobarbituric acid-malonaldehyde (TBA-MDA) adduct formation. As shown in Fig. 6, concentrationdependent inhibition of hydroxyl radical-induced deoxyribose degradation was observed in both site-specific and non-sitespecific assays. However, significantly greater anti-oxidant activity was observed in the site-specific assay than in the non-site-specific assay when the same concentration of REEE-1 was used. This result implies that REEE-1 chelates 


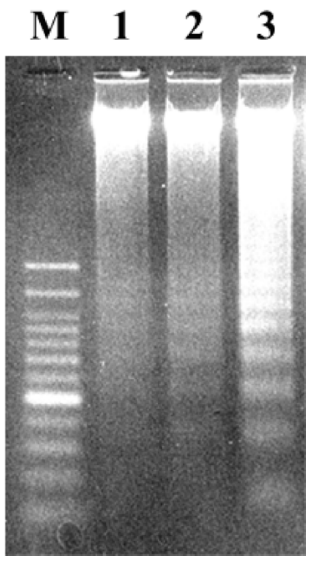

Fig. 5. Analysis of DNA fragmentation using agarose gel electrophoresis. Jurkat cells were incubated in the presence of 1 to $10 \mu \mathrm{g} / \mathrm{ml}$ of REEE-1 for $24 \mathrm{~h}$. Genomic DNA was prepared as described in Materials and Methods, and analyzed by $2 \%$ agarose gel electrophoresis followed by ethidium bromide staining. Lanes show results from a control sample (lane 1) and samples treated with $1 \mu \mathrm{g} / \mathrm{ml}$ (lane 2) and $10 \mu \mathrm{g} / \mathrm{ml}$ (lane 3) of REEE-1. A representative result from three independent experiments is shown. M represents a 100-bp DNA size marker.

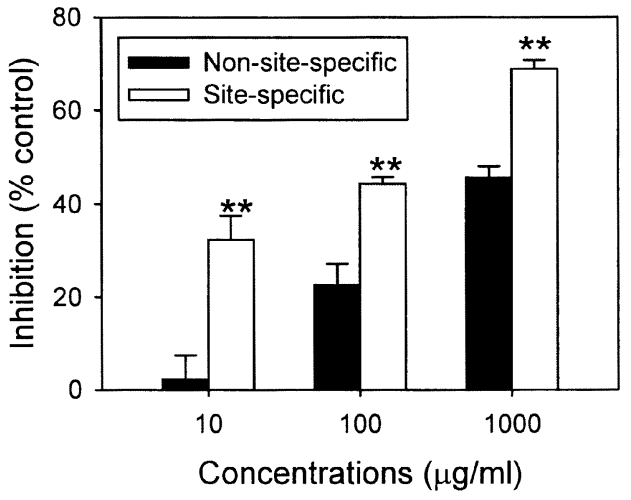

Fig. 6. Inhibitory effects of REEE-1 on hydroxyl radicalmediated deoxyribose degradation. Hydroxyl radicals were generated by Fentons reaction using a deoxyribose assay system. The non-site-specific ( $\square$ ) and site-specific ( $\square$ ) scavenging activities of hydroxyl radicals by REEE-1 are expressed as the \% inhibition. The results are the mean SE of triplicate experiments. $* * P<0.01$ indicates significant differences between the experiments at the same concentrations tested.

metal ions rather than scavenging hydroxyl radicals directly. In contrast, when the ability of REEE- 1 to reduce the $\mathrm{Fe}^{3+}$ EDTA complex was tested to examine its pro-oxidant activity, there was weak pro-oxidant activity at low concentrations in the absence of ascorbic acid (Table 1), but not in the absence of both ascorbic acid and EDTA (data not shown). As shown in the table, however, the pro-oxidant effect was not observed when $1 \mathrm{mg} / \mathrm{ml}$ of REEE- 1 was used.

Next, we tested the anti-oxidant effect of REEE-1 on superoxide anions by monitoring the reduction of NBT
Table 1. Pro-oxidant effect of REEE-1 on iron-dependent hydroxyl radical generation

\begin{tabular}{ccc}
\hline $\begin{array}{c}\text { Amount of REEE-1 } \\
(\mu \mathrm{g} / \mathrm{ml})\end{array}$ & $\begin{array}{c}\text { Optical density } \\
\left(\mathrm{A}_{532} \mathrm{~nm}\right)\end{array}$ & $\begin{array}{c}\text { Stimulation } \\
(\%)\end{array}$ \\
\hline Control & $0.151 \pm 0.023$ & \\
\hline 10 & $0.116 \pm 0.006$ & 0 \\
50 & $0.164 \pm 0.020$ & 8.6 \\
100 & $0.225 \pm 0.005$ & 49.0 \\
1000 & $0.140 \pm 0.003$ & 0 \\
2000 & $0.126 \pm 0.008$ & 0 \\
\hline
\end{tabular}

Experiments were conducted essentially as described by Halliwell et al. (1997) with slight modification as described in the Materials and Methods. Control contained the reaction buffer solution only. The pro-oxidant effect of REEE-1 was expressed as \% stimulation, which was calculated as follows; \% stimulation $=\left[\left(\mathrm{OD}_{\text {sample }}-\mathrm{OD}_{\text {control }}\right) / \mathrm{OD}_{\text {control }}\right] \times 100$. The results are the mean values of three separate experiments.

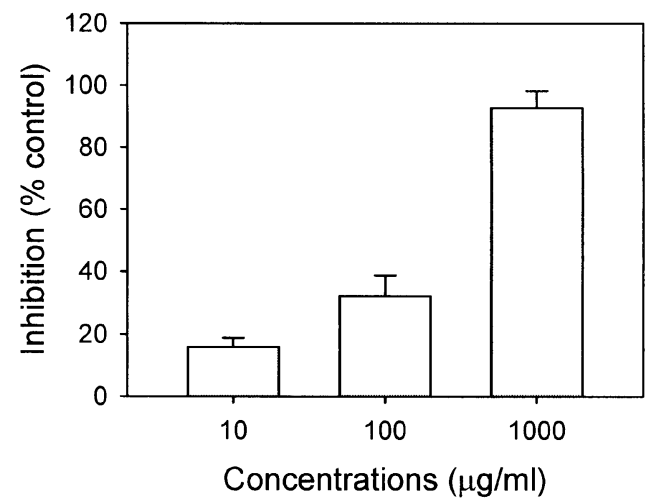

Fig. 7. Inhibitory effect of REEE-1 on NBT reduction. The inhibitory effect of REEE-1 was tested by monitoring NBT reduction caused by superoxide anions using the hypoxanthinexanthine oxidase system as described in Materials and Methods. The results are expressed as the mean $\pm \mathrm{SE}$ of triplicate experiments.

induced by superoxide anions produced by the xanthine oxidase-mediated degradation of hypoxanthine. REEE-1 inhibited NBT reduction very efficiently (Fig. 7). Superoxide anion production was inhibited by $32.3 \%$ when $0.1 \mathrm{mg} / \mathrm{ml}$ of REEE-1 was added to the reaction solution. However, when $1 \mathrm{mg} / \mathrm{ml}$ of REEE-1 was added, almost complete inhibition (around 90\%) of superoxide anions was seen. Considering the results of the deoxyribose assay, these data indicate that REEE-1 is more active in scavenging superoxide anions than hydroxyl radicals under the conditions reported here.

\section{Discussion}

The main goal of this study was to investigate the effect of REEE-1 on cell proliferation and apoptosis induction in 
human lymphoma cell lines. Initially, we showed that REEE-1 treatment induced active inhibition of DNA synthesis in cultured lymphoma cells (Fig. 1). This result is in agreement with a previous study showing that an ethanol extract of RVS strongly inhibited proliferation in tumor cells (Lee et al., 1999a). In addition, since cell numbers to exclude trypan blue staining decreased with increased treatment time or treatment dose (Fig. 2), we believe that the REEE-1-mediated inhibition of DNA synthesis may be exerted through a cytotoxic effect, rather than a cytostatic effect. We subsequently investigated whether the cytotoxic effect is mediated via an apoptotic mechanism. As evidenced by the increase in positively stained cells in the TUNEL assay (Fig. 3), the presence of many cells with low-level PI fluorescence (Fig. 4), and the characteristic fragmentation of nucleic DNA (Fig. 5), it appeared that apoptosis was the main mechanism for cell death induced by the presence of REEE-1.

Since it has been suggested that apoptosis plays a critical role in tissue homeostasis and cancer development, apoptosis modulation has become an interesting target for both therapeutic and preventive approaches to cancer treatment (Ahmad et al., 1997). Although the exact intracellular mechanisms of REEE-1-mediated apoptosis of lymphoma cells were not clearly elucidated in the present study, other reports suggest that many naturally occurring substances might regulate the activity of intracellular kinases and/or the balance between intracellular redox states, thereby arresting cell growth and inducing apoptotic cell death in several carcinoma cell lines. For example, some phytochemicals, such as flavonoids and vitamins, are specific inhibitors of protein kinase C (Gamet-Payrastre et al., 1999) or protein tyrosine kinase (Yang et al., 1998), and are potential inducers of apoptosis in tumor cells (van Poppel and van den Berg, 1997; Paschka et al., 1998). More importantly, our previous report suggested that REEE-1 may scavenge free radicals and stimulate a toxic signaling pathway, such as the fas pathway (Lee et al., 2001). Therefore, we believe that REEE-1 induces apoptotic cell death in human lymphoma cells through the modulation of a redox-related signaling factor and that the modulation is also associated with REEE-1 anti-oxidant properties. However, the in vitro mechanism(s) by which REEE-1 induces apoptosis of the cells, and the in vivo REEE1 anti-tumor properties remain to be determined.

In addition, relatively greater inhibition against hydroxyl radical-mediated deoxyribose degradation was observed in the site-specific assay than in the non-site-specific assay (Fig. 6). This result suggests that REEE-1 inhibits deoxyribose degradation by chelating iron ions rather than by scavenging hydroxyl radicals directly. Further, the ability of REEE-1 to reduce the $\mathrm{Fe}^{3+}$-EDTA complex, which represents its ability to stimulate hydroxyl radical generation (Aruoma et al., 1997), was not observed when high concentrations of REEE-1 were added (Table 1). This indicates that the pro-oxidant activity of REEE-1 was readily overwhelmed by the anti-oxidant potential of the extract. Furthermore, since superoxide anions produce other kinds of cell-damaging free radicals and oxidizing agents (Liu and $\mathrm{Ng}, 2000$ ), the potential scavenging of superoxide anions by REEE-1 (Fig. 7) strongly suggests that REEE-1 could be used as an efficient natural anti-oxidant. Collectively, these results suggest that the active inhibition of cell growth and the induction of apoptosis by REEE-1 are associated with its anti-oxidant potential.

In this study, we demonstrated that REEE-1 inhibits the proliferation of human lymphoma cells and induces cell death by apoptosis. Moreover, the extract exhibited potential free radical scavenging activity and iron ion chelating activity, which could eliminate oxidative stress generated by free radicals whose removal is beyond the capacity of a biological system. Therefore, we speculate that REEE-1 could be used as a cancer chemopreventive and therapeutic agent. We are currently studying the intracellular mechanisms of the induction of apoptosis by REEE-1 and are characterizing its active ingredients.

Acknowledgments This work was supported by the grant from the Korean Ministry of Science and Technology and from Chollabukdo Province in support of regional research and development. Part of this work was conducted at the Research Center of Bioactive Materials of Chonbuk National University. Dr. J. Kim was supported by the Chonbuk National University Post-Doctoral Fellowship Program.

\section{References}

Ahmad, N., Feyes, D. K., Nieminen, A. L., Agarwal, R. and Mukhtar, H. (1997) Green tea constituent epigallocatechin-3gallate and induction of apoptosis and cell cycle arrest in human carcinoma cells. J. Natl. Cancer Inst. 89, 1881-1886.

Aruoma, O. I., Spencer, J. P. E., Warren, D., Jenner, P., Butler, J. and Halliwell, B. (1997) Characterization of food antioxidants, illustrated using commercial garlic and ginger preparations. Food Chem. 60, 149-156.

Christou, L., Hatzimichael, E., Chaidos, A., Tsiara, S. and Bourantas, K. L. (2001) Treatment of plasma cell leukemia with vincristine, liposomal doxorubicin and dexamethasone. Eur. J. Haematol. 67, 51-53.

Farr, D. R. (1997) Functional foods. Cancer Lett. 114, 59-63.

Gamet-Payrastre, L., Manenti, S., Gratacap, M. P., Tulliez, J., Chap, H. and Payrastre, B. (1999) Flavonoids and the inhibition of PKC and PI 3-kinase. Gen. Pharmacol. 32, 279286.

Gotoh, N. and Niki, E. (1992) Rates of interactions of superoxide with vitamin $\mathrm{E}$, vitamin $\mathrm{C}$ and related compounds as measured by chemiluminescence. Biochim. Biophys. Acta 1115, 201-207.

Halliwell, B., Gutteridge, J. M. C. and Aruoma, O. I. (1987) The deoxyribose method: simple "test-tube" assay for determination of rate constants for reactions of hydroxyl radicals. Anal. Biochem. 165, 215-219.

Hong, D. H., Han, S. B., Lee, C. W., Park, S. H., Jeon, Y. J., Kim, M. J., Kwak, S. S. and Kim, H. M. (1999) Cytotoxicity of urushiols isolated from sap of Korean lacquer tree (Rhus 
verniciflua Stokes). Arch. Pharm. Res. 22, 638-641.

Hongo, T., Mizuno, Y., Haraguchi, S. and Yoshida, T. O. (1986) A new anticancer drug sensitivity test using the microplate culture and surviving tumor cell staining method. Gan To Kagaku Ryoho 13, 247-254.

Jung, N. C. (1998) Biological activity of urushiol and flavonoids from Lac tree (Rhus verniciflua Stokes). Ph.D. thesis, Chonnam National University, Kwang-ju, South Korea.

Kitts, D. D., Wijewickreme, A. N. and Hu, C. (2000) Antioxidant properties of a North American ginseng extract. Mol. Cell. Biochem. 203, 1-10.

Lee, J. C., Jung, H. Y. and Lim, K. T. (1999a) Effects of Rhus verniciflua stokes (RVS) on the plasma level of cholesterol and tumor growth in mouse. J. Toxicol. Pub. Health 15, 169-175.

Lee, J. C., Kim, J., Lim, K. T., Yang, M. S. and Jang, Y. S. (2001a) Ethanol eluted extract of Rhus verniciflua Stokes showed both antioxidant and cytotoxic effects on mouse thymocytes depending on the dose and time of the treatment. $J$. Biochem. Mol. Biol. 34, 250-258.

Lee, J. C. and Lim, K. T. (2001b) Inhibitory effects of the ethanol extract of Ulmus davidiana on apoptosis induced by glucoseglucose oxidase and cytokine production in cultured mouse primary immune cells. J. Biochem. Mol. Biol. 34, 463-471.

Lee, T. E., Park, S. W. and Min, T. J. (1999b) Antiproliferative effect of Artemisia argyi extract against J774A.1 cells and subcellular superoxide dismutase (SOD) activity changes. $J$. Biochem. Mol. Biol. 32, 585-593.
Lim, K. T., Lee, J. C., Jung, H. Y. and Jo, S. K. (2000) Effects of Rhus verniciflua Stokes (RVS) on cell-associated detoxificant enzymes and glucose oxidase-mediated toxicity in cultured mouse hepatocytes. J. Toxicol. Pub. Health 16, 125-131.

Liu, F. and Ng, T. B. (2000) Antioxidative and free radical scavenging activities of selected medicinal herbs. Life Sci. 66, 725-735.

Mukherjee, A. K., Basu, S., Sarkar, N. and Ghosh, A. C. (2001) Advances in cancer therapy with plant based natural products. Curr. Med. Chem. 8, 1467-1486.

Paschka, A. G., Butler, R. and Young, C. Y. F. (1998) Induction of apoptosis in prostate cancer cell lines by the green tea component, (-)-epigallocatechin-3-gallate. Cancer Lett. 130, 17.

Pezutto, J. M. (1997) Plant-derived anticancer agents. Biochem. Pharmacol. 53, 121-133.

Smets, L. A. (1994) Programmed cell death (apoptosis) and response to anti-cancer drugs, Anticancer Drugs 5, 3-9.

van Poppel, G. and van den Berg, H. (1997) Vitamins and cancer. Cancer Lett. 114, 195-202.

Wang, H., Cao, G. and Prior, R. L. (1997) Oxygen radical absorbing capacity of anthrocyanins. J. Agric. Food Chem. 45, 304-309.

Yang, E. B., Zhang, K., Cheng, L. Y. and Mack, P. (1998) Butein, a specific protein tyrosine kinase inhibitor. Biochem. Biophys. Res. Commun. 245, 435-438. 